\title{
Literacy Practices in Some Folklores from Madura
}

\author{
Mamik T. Wedawati ${ }^{1, *}$ Much. Khoiri ${ }^{1}$ Dwi N. C. S. Kusumaningtyas ${ }^{2}$ \\ ${ }^{1,2}$ Faculty of Languages and Arts, Universitas Negeri Surabaya, Indonesia \\ *Corresponding author. Email: mamikwedawati@unesa.ac.id
}

\begin{abstract}
Defining the literacy practices in three folklores, written by Zawawi Imron, include Joko Taal, Ni Peri Tanjung Wulan, and Karapan Sapi is the purpose of the study. Some books of the folklore, journals articles, and textbooks that cope a theory from Barton and Hamilton explaining literacy practices and their manifestation discussion into library research which fully apply qualitative research. Three stories represent the culture, people, customs, language, and identity of the Madurese. Results of the discussion include five criteria of literacy practices in some aspects of the character life. They are a series of social practices which can be traced from various events in which written texts are involved. The manifestation of the literacy practices toward the characters also meets its need. Five details can be found in the text include management of daily life, personal communication, private leisure, and sense of making in oneself and the environment, and social participation. The idea of documenting life still needs further analysis since the stories do not cope with the pictures of it.
\end{abstract}

Keywords: Folklore, Literacy practices, Literacy.

\section{INTRODUCTION}

Literacy refers to some ideas, two of them two main perspectives in the study of literacy, namely the cognitive psychology approach and the sociocultural approach. Street calls it the autonomous model of literacy and the ideological model of literacy [1]. Based on a cognitive psychology approach with an autonomy model, literacy is a set of knowledge and skills (reading, writing, listening, and speaking) that are acquired at certain ages and must be taught and developed in the same way [2]. In this sense, literacy is considered a skill that can be learned and taught regardless of the context and background of the learner (hence it is called autonomous).

In the sociocultural perspective or ideological model, Street states that literacy is how language is being used and the development of cognitive skills associated with social practices involving cultural phenomena [3]. It means that literacy skills are not skills that stand alone and they are part of the culture in order to learn and teach them or rather introduce them through socializing people need to pay attention to the sociocultural background of the learner. Therefore, Street initiated the idea of local literacy, namely that because literacy is associated with social practices, social practices from one community to another are certainly different [3]. So, literacy is not the same in all contexts, according to the circumstances of the community. What can be done by a society with a written culture in a given condition can be done in a different way in a society with a speech culture with more or less the same results. Because literacy is considered as part of the culture and social practice that is meant by literacy is done and can be done by reading and writing and oral [3]. Perez (in Edwards) says that based on this sociocultural view, being literate means being able to read and write appropriately according to the cultural context [4].

As for the framework of the language socialization paradigm, building a literacy culture is building a literacy habitus or building a literacy habit [5]. Habits are what people do over and over and become a culture in their lives. This habit is manifested through socialization which is usually done through language or to use of language, as the concept of language socialization was initiated by Ochs and Schieffelin [5]. A child who grows up in a community will definitely interact with the people around him, both older people and their peers. In this interaction, a child will learn and internalize what is experienced, seen, or heard. In the process, he acquires knowledge about existing social practices and how he can participate in and at the same time acquires this identity. This is what Sterponi calls a cultural apprenticeship [5]. The family, school, and community are the closest 
environment where three institutions, children gain various social experiences, including literacy experiences and deals with language; language socialization.

A story where there are many aspects had happened through characters coverage the events come up in the traditional stories, folklore. Bascom (in Sims and Stephens) argues that folklore is a way of communicating values and informing Community groups [6]. According to Bascom, in folklore, there are four functions: Integrity, namely the function of education, a means of escape from cultural boundaries that Acceptance, maintaining cultural identity, and validating existing cultural norms. Thus, folklore is one of the important mechanisms in maintaining cultural stability [6]. When literacy talks not only various productive and receptive activities at school or any context where all skills are correlated one into another, folklore gives different facts.

Folklore from Madura is one of the thousands that able to reveal the social practices of literacy activities since its storyline shows many social experiences towards how all life aspects will deal with all language skills. Sukmawan and Febriani have started discussing folklore in Tengger with a focus on entrepreneurship, education, conservation, and literacy in cultural aspects [7]. The study of Aziz is about literacy in folklore (transmission of character) [8], and Halimatussakdiyah, Yuda, and Junaidi did research on Literacy on Literature with the focus on folklore at elementary school [9].

This study will explore the literacy practices and the manifestation of those literacy practices toward Madurese people that are kept on the folklore from Madura, especially written again by a famous author, Zawawi Imron. The folklore titles Jaka Taal, Ni Peri Tunjung Wulan, and Karapan Sapi.

\subsection{Folklore from Madura}

Folklore is a part of literature that appears and grows in society Madura. The Madurese people value literature as a knowledge reserve. Madura has given a wide space for information or about how to People in ancient times can survive, about how they interact and build on their high ancient cultures. Sometimes, in the Madura literature, there is scientific information that makes no sense but it turns out that in the future, it will actually happen.

The Madurese people value folklore as the main thing in conveying and passing on the noble values of a nation, especially its moral teachings. Every region in Madura, folklore that contains noble values and has many varieties. This diversity makes Madura rich in cultural values. There are many features of folklore; this cultural work really needs to be considered as a sign of societal change. Folklore in society can voice behaviour Process of educating the people around them. In the changes that occur, there is a process of recognition Continuous culture. Inheritance of values and conceptions of the Madurese community through the story has been passed down from generation to generation. These stories do not just reflect the values of sociocultural society in the past but also deliver these values to the community.

Now. This is because stories in one generation are inherited from people's stories previously [10]. Madurese folklore has uses in the life of a collective, For example, as an educational tool, consolation, social prestige and projection of desire Hidden. The predecessors of the Madurese community everywhere have always instilled values and conceptions which are then believed to be the blueprints that guide In the course of his life. Values and conceptions that guide behaviour; Hard and tough, religious, glorify paternalistic, regard cows as assets.

\subsection{Literacy}

Based on the definition of literacy from two major perspectives in literacy studies and concepts that are widely discussed by literacy and anthropology scholars, as well as language socialization experts, it can be concluded that literacy skills based on the perspective of cognitive psychology are the ability to recognize sounds, the ability to recognize letters, the ability to represent sounds.

Literary literacy includes receptive and productive abilities in an effort to discourse on local literature in writing and orally. Literary literacy specifically can be included in the mastery and appreciation of the culture of a region. Literary literacy is a path leading to a change and improvement of children's literacy with methods and techniques for empowering intellectual literacy, and it requires language skills, listening, speaking, reading, writing, both starting from the family environment, around the house, and the school environment. Literary literacy needs to be developed in schools, including literature and art, which become a means of identifying the nation (Indonesian literature as part of the "heirs of the nation's World culture").

\subsection{Literacy as a Social Practice}

To understand literacy as a social practice, it is necessary to first understand the concepts that underlie these ideas, including literacy practice and literacy events. Barton and Hamilton define literacy practices as follows: Literacy practices are the general cultural ways of utilizing written language which people draw upon their lives [11]. Literacy practice is a common way or habit to use written language that is used in everyday life.

Furthermore, Barton and Hamilton explain that literacy events are activities where literacy has a role, meaning that literacy events are all activities in which literacy is a part. More simply, the practice of literacy is all activities carried out with literacy [11]. Meanwhile, 
literacy events can be interpreted as events or events that can be observed that will always involve values, attitudes, feelings, and social relationships, while literacy events are components of the literacy practice that can be seen and observed.

Many literacy events in life are regular and repetitive activities. Some literacy events are in the form of routine work that is part of a formal procedure or the demands of a particular social institution, such as a workplace, school, or even at home. For example, a person goes to a bank and fills out a transaction form. This activity is an event that involves literacy. The literacy practice carried out is the activity of filling out the form. This activity connects literacy with social practice, namely in relation to the banking system.

In the book Situated Literacies, Barton and Hamilton also provide several important concepts for understanding literacy as a social practice [12], they are:

(1) Literacy is interpreted as a series of social practices, which can be traced from various events in which written texts are involved.

(2) Literacy practices are shaped by social institutions and power relations.

(3) The practice of literacy has a specific purpose and is closely related to social goals and cultural practices in general.

(4) Literacy occurs in a historical context.

(5) Literacy practices are always changing, and new literacy practices are often acquired through informal learning and meaning formation processes.

Learning and gaining meaning can be obtained not only in formal education but can also be obtained from life experience and literacy as part of the learning. Each individual must realize that literacy is an important aspect of the learning process also literacy practices are part of the influence in the learning process.

\subsection{The Meaning and Function of Literacy in Social Life}

It requires a deep understanding that literacy is closely related to daily activities. In this case, literacy is not only centred on reading and writing activities. There is another goal to be achieved with the help of reading and writing activities, and this goal is closely related to broader social relations. In a social view, literacy does not only focus on individual proficiency and the use of these skills but rather on how to utilize literacy practices in everyday life.

Literacy practices will provide their own meaning and function for the perpetrators, depending on the ultimate goal to be achieved and also their relationship with the people involved in the practice. Literacy as a social practice has various functions, including regulating daily life, personal communication, personal enjoyment, documentation of personal life, the meaning of self and environment as well as social participation.

In another book, Barton and Hamilton describe several examples of how literacy can bring various meanings and functions to the lives of its practitioners [12], they are

(1) Organizing life (managing daily life)

(2) Personal communication (personal communication)

(3) Private leisure (private pleasure)

(4) Documenting life (documentation of life)

(5) Sense making (meaning oneself and the environment)

(6) Social participation (social participation in life as social beings) participate in social activities, both in small groups such as families, or in a wider environment such as groups and communities.

This social participation can involve literacy in many ways, for example attending RT or youth association meetings, writing open letters, signing environmental petitions on Facebook, drawing graffiti or posting announcement posters, or other activities that represent and relate to a particular group. In fact, it is not uncommon for one literacy practice to form a certain social community, such as the blogger community, the JK book reader association, Rowling, and so on.

\section{METHODS}

This research will be conducted by applying a literature study (Library Research). With library studies, the research team will collect information and data with the help of various sources in the library such as documents, books, magazines, historical stories, etc. [13]. In other elaboration, literature study can be a number of activities including those relating to the method of collecting library data, reading and recording and processing research materials on data collection techniques by conducting in-depth readings on books, literature, notes, and reporting related problems to be solved. Another thing in the reading process is very likely to be connected with culture, values, norms that arise and develop according to the situation that existed at the time the research was conducted. In the literature study, the team was also able to conduct an in-depth reading of reference books and similar previous research results that were useful for obtaining a theoretical basis for the problem to be solved. With good planning, this research will proceed with the following procedures: (1) Topic selection, (2) Information exploration, (3) Determining the research focus, (4) Data source collection, (5) Data presentation preparation, (6) Report preparation. 
The data collection technique in this study is documentation, which is looking for data about ideas or variables to be discussed in the form of notes, books, papers or articles, journals and so on. In carrying out a literature study, there are four main characteristics that must be considered, namely: 1) researchers deal directly with the text of folklore books, 2) library data is direct, meaning that researchers deal directly with data sources in the library, 3) library data are generally secondary sources. , in the sense that the researcher obtains material or data from the second hand and not the original data from the first data in the field, 4) the condition of the library data is not limited by space and time [13]. Data collection in the study was carried out by reviewing and/or exploring folklore books written by Zawawi Imron, including the titles: Joko Taal, Ni Peri Tanjung Wulan, and Karapan Sapi, several journals, books, and documents (both printed and printed Electronic), as well as other sources of data and information, deemed relevant to the research or study.

\section{RESULTS AND DISCUSSION}

Folklore tells a lot about what had happened in humans' life, especially when it talks about how people in certain eras live a life. Stories from Madura are one genre of folklore where else others may talk about folk speech, traditional utterances, poems, prose/stories (fable, myth, folktales, legend, etc.), and songs [14]. Madura folktales have already become a topic of discussion in several studies. Imron studied some stories from Madura which full of religious and moral values [15]. Describing how far do Madura people live with so many values shown clearly in five short stories. Furthermore, Barton and Hamilton explain that literacy events are activities where literacy has a role, meaning that literacy events are all activities in which literacy is a part. More simply, the practice of literacy is all activities carried out with literacy [11]. Meanwhile, literacy events can be interpreted as events or events that can be observed that will always involve values, attitudes, feelings, and social relationships, while literacy events are components of the literacy practice that can be seen and observed.

\subsection{Literacy Practices}

Barton and Hamilton explain that literacy as social practices will talk a lot about how someone gets to interact with all daily life activities that can be interpreted as events or events that involve values, attitudes, feelings, and social relationships when they deal with all things related into reading and writing [16].

The first criteria of literary as social practices is a literacy that is interpreted as a series of social practices which can be traced from various events in which written texts are involved in the first stories titled Joko Taal. In the story of Jaka Taal, Jaka starts the informal education studying about Islam from the person he respects very well.

Setelah pesta usai, Joko Taal mulai belajar mengaji oleh kiai sendiri. (JT, 28)

The context of mengaji means that there is a literacy practice, studying a certain topic including reading a book and sometimes listening to the lecturing from the teacher explaining about the ideas written on the book. The chance Jaka Taal get is very special since Jaka learns it directly with the senior teacher in that informal school.

Ada yang mengobati sang putri dengan keris, ada yang memberi minum air yang dibawa dari pertapaan dan ada pula yang mulutnya komat-kamit membaca doa-doa agar putri Andawiyah sembuh dari sakitnya. (JT, 32-33)

Literacy practices in Ni Peri Tanjung Wulan also exist among the citizen context, especially when there will be an announcement from the kingdom (a governmental system). The soldier who gets a task deliver it to people have to be able to deliver it very clear in front of a lot of people with a loud voice.

Di sana seorang petugas dari keraton sedang bersiap untuk memberikan pengumuman. Setelah seluruh rakyat kampung berkumpul, petugas itu berdiri lalu berpidatodengan suara keras adar didengar oleh semua yang hadir [,...] (NPTW, 31)

From the same title, Ni Peri Tanjung Wulan gives other pictures of how literacy is being practiced by the character in the story.

Kalau siang hari ia datang ke sawah-sawah dan ladang-ladang memberi semangat dan petunjuk kepada para petani agar lebih giat lagi mengolah tanahnya. Serta dihiburnya petani-petani itu dengan cerita-cerita yang mengandung pendidikan sehingga keakraban antara raja dan rakyat semakin mantap. (NPTW, 18)

Meanwhile, the activity of Karapan Sapi does many things in daily life represents literacy practices. The idea of writing a letter and reading the letter are two main activities of doing literacy activity.

[...] Lama benar engkau tidak berkirim surat kepadaku. Saat ini kesempatan menulis surat kepadamu, semoga engkau menerimanya dengan senang hati $[\ldots](K S, 1)$

The second criterion of doing literacy shows at the time the social institutions and power relations take a part in the activity [11]. The number of the representation of the institution from the society who is doing literacy practices is not as much as those in the 1 st criteria. Since the three stories (Joko Taal, Ni Peri Tanjung Wulan, and Karapan Sapi) talk more about the characters personal conflict and how each of them solve their problems. In 
the Joko Taal, the representation of social institution and power relations could be seen when he finally is accepted by an educational institution and will be taught by a senior teacher which has been called by "Kiai". The existence of "Kiai" is the representation of the one who has power. The power relation goes to the relation between Jaka who will be the student and "Kiai" as the teacher who has the knowledge and knows many where Jaka interested to study about.

In the story of Ni Peri Tanjung Wulan, how does institution and power relation being represented then become the minor focus since this value is really rare being shown on the story. The only representation of it is written when there are soldiers who will give an announcement to the wide-open society.

As the third criteria, the activity which has a specific purpose and is closely related to social goals and cultural practices in general could be found in Jaka Taal, Ni Peri Tanjung Wulan, and Karapan Sapi. In this context, what the characters have done is not only about the idea they do. Furthermore, after that first deed, it drives to others that is the goal related to social or cultural context. In Jaka Taal, it has been said that there is someone who tries to cure the princess through water that has been given prayers.

Ada yang mengobati sang putri dengan keris, ada yang memberi minum air yang dibawa dari pertapaan dan ada pula yang mulutnya komat-kamit membaca doa-doa agar putri aandawiyah sembuh dari sakitnya. (JT, 32-33)

The prayers and the ideas of delivering it for the purpose of curing someone is already part of literacy. However, the prayers can go alone in the process of curing. Water and 'keris' element take important rule as the media how the prayers say in front of the water and tend to deliver it to the water would believe that the treatment is success and princess is fine. Believing the method using 'keris' and delivering the prayers through water is part of literacy practices from the social and cultural.

When the people work on the rice field, $\mathrm{Ni}$ also goes to the field giving them support psychologically and entertaining them through stories talking about education, etc., (NPTW, 18) so that they get closer more than only between the king and his people.

Another representation of literary practice in social and cultural context from Karapan Sapi could be seen in the session when the students follow many activities at school studying lesson with a male teacher, Rahman goes to the post office to deposit his money, and when the teacher asking Rahman and friends sing 'Indonesia Raya'. These three activities give another context where literacy practices are real in many aspects of human life. When Rahman goes to the post office with Ito, Ito remembers very well that Rahman has passed many moments to add his deposit. It reminds Rahman that Rahman must start again depositing his money regularly since he really wants to go to Madura with his saving. Effort to get back again willing to save his money, Rahman has started his being disciplined and appreciated Ito's suggestion that is part of social and cultural goals.

Singing 'Indonesia Raya' is not only reading, memorizing, and singing the lyrics, but when they sing it seriously, with a clear, beautiful, and strong voice, they and others will enjoy it more and love Indonesia more than before. The social goal from the activity of singing is to interact with other Indonesian to love Indonesia more than before and transfer the energy positive.

The representation of informal learning and meaning formation processes in the story is part of literacy practices. In Joko Taal, Ni Peri Tanjung Wulan, and Karapan Sapi show good pictures of how informal learning and meaning formation could be seen.

Jaka Taal is a story that build the story from the idea of a good son who has been suffered from how his stepmom treated him even had made a plan to kill him but failed. In Joko Taal, the representation of informal learning had happened when Joko decided to study with 'Pak Kiai'. Where does the school, who is the teacher, how does the school could educate Joko, are part of the informal learning. In Ni Peri Tanjun Wulan, the representation of literacy practices is shown when the activity of transferring the education topic while doing planting rice seed and etc. at the rice field and plantation where villagers meet their king not in a formal situation. Another place is in public places, such as in the city park/garden near/ close the center of the city. While in Karapan Sapi, there are several plots where Rahman, Ito, and other characters get involved in the activities at the school, post office, and library where these three places be the main place that direct the characters experiencing literacy practices.

The last practices of literacy could be seen from the historical context that being built by the story through the character. However, Joko Taal, Ni Peri Tanjung Wulan, and Karapan Sapi are actually talking more about the events that are not documented as the historical assets. The story itself is not a story about war or phenomenal event or accident. However, the name of the characters somehow already tells the reader that they are people who is famous when Madura started his own history through stories. The folklore from Madura that has been studied by some researchers giving a fact that there are many moral value; Azhar [17], Effendy [18], Sulaiman [19], Hefni [20], Azhar [21], and Sri Utami [22]. Each of their study talk different ideas which is still about folklore from Madura. 


\subsection{Manifestation of Literacy Practices in the Stories}

The stories of Joko Taal, Ni Peri Tanjung Wulan, and Karapan Sapi talk about a character which originally from Madura. They were born, grew, and lived in Madura Island. Madura as the place where they got all complete life's value which presents many realities how do they experience many activities deal with literacy has been captured by many stories including the folklore written by $\mathrm{Z}$. Imron.

Literacy practices as can be seen Joko Taal, Ni Peri Tanjung Wulan, and Karapan Sapi has already kept a manifestation to the character in the story and showed some facts consisting of six criteria [12]. These six criteria have been explained clearly by Barton already covered the literacy practices which direct able to give manifestation to the life of the character in two modes, personal and social aspect. The characters in Joko Taal, Ni Peri Tanjung Wulan, and Karapan Sapi could be seen as personal and also as part of the social environment since three of them are not a character who isolate their life and do nothing. However, all deeds what has been done by them could not be justified as the representation achieving these six manifestations.

In the Joko Taal, Joko Taal who really wants to study finally could found 'Pak Kiai' who is willing to teach him. Some prerequisite from 'Pak Kiai' has to be fulfilled by Joko such as shepherd 'Pak Kiai' goats every time before they learn something. Doing this precondition already be a manifestation toward Joko that he does personal communication considering his willing personal study with 'Pak Kiai'. While going shepherd before learning with 'Pak Kiai', Joko also has oneself goal or Barton give a term as sense-making (meaning oneself). Since doing shepherd depends on the person who does and spends his time, actually he could learn something from what he has experienced with seven goats. Even, doing shepherd is 'Pak Kiai' initiative, Joko is the one who will learn and get the indirect benefit of all.

Ni Peri Tunjung Wulan is a story about a good young man who gets a blessing being accompanied by a beautiful fairy from the sky and both of them has a child whom they love so much. The character Arya, has already become a complete person since personally and as part of society. Arya, with good quality as a man except dealing with his love, the beautiful fairy. Arya often goes to the rice field to talk with many people who work there. Moreover, he often tells stories to people in the field that are full of educational value. By this, there is no border anymore between the king and the people. This will make the communication and relationship between them will run very well. The manifestation toward the character as personal could be experienced in the context that Arya already organized his life so well, having personal communication with many people, having good social participation, and enjoying his private leisure since meeting others and telling stories can bring happiness to him and people. As personal, Arya also knows well all that he does without a purpose since keeping the fairy still next to him is part of his sense making. The one is not clear as the manifestation of Arya, documenting life. The story of Joko Taal has already become famous and the identity of Madura. However, that there is a session of recording it, still need to be discussed further in a different article.

The story of Karapan Sapi, through the character Rahman who has a representation as a good young man, gets some manifestation from literacy practices that were experienced by Rahman. Rahman is a young man who has a dream of going to Madura and getting involved in a big competition that is already become a proudness he wants to achieve. The plot while Rahman and his friend, Ito at school and public places (post office, library) and doing something together with many people, such as singing Indonesia Raya, they have done a manifestation toward his life. Rahman not only does personal and social communication, gets private leisure, sense making, but he also has already shown that he is able to organize his life. Documenting life for Arya, could not be derived directly as the manifestation of literacy practices since another analysis needs to be done before composing the same as another rule.

\section{CONCLUSION}

Story of Joko Taal, Ni Peri Tanjung Wulan, and Karapan Sapi as the representation of the culture, people, custom, language, and identity of the people ffrom Madura, these three artwork has already give pictures that direct and directly literacy practices could be seen on the text. These five criteria of literacy practices could be found in some aspects of life of the character, they are a series of social practices (which can be traced from various events in which written texts are involved), social institutions and power relations, social goals and cultural practices in general, and informal learning and meaning formation processes. One criterion that is difficult to say that it is a kind of historical context that exist in the characters' life since it is not about war and part of a historical event. The manifestation of the literacy practices toward the characters also meets its need. Five details can be found in the text; they are organizing life (managing daily life), personal communication, private leisure, and sense making (meaning oneself and the environment), and social participation (social participation). The idea of documenting life still needs further analysis since the story does not cope with the pictures of it. 


\section{REFERENCES}

[1] S. Reder and E. Davila, "Context and literacy practices," Annu. Rev. Appl. Linguist., vol. 25, pp. 170-187, 2005. DOI: 10.1017/S0267190505000097

[2] K. Goouch and A. Lambirth, Understanding Phonics and the Teaching of Reading: Critical Perspectives. Maidenhead: Open University Press/McGraw-Hill, 2008.

[3] B.V. Street, Literacy and Development: Ethnographic Perspectives. Routledge, 2001.

[4] K.S. Edwards, "Teaching and Defining Literacy Through a Sociocultural Lens," in The UWI Quality Education Forum, no. 24, 2020, pp. 104-113. [Online]. Available: https://journals.sta.uwi.edu/qef/index.asp?action=d ownloadArticle \&articleId $=7839 \&$ galleyId $=6875$

[5] A. Duranti, E. Ochs, and B.B. Schieffelin, The Handbook of Language Socialization. WileyBlackwell, 2012.

[6] M.C. Sims and M. Stephens, Living Floklore: An Introduction to the Study of People and Their Traditions, 2nd ed. Logan: Utah State University Press, 2011.

[7] S. Sukmawan and R. Febriani, "Folklor Tengger: Literasi Harmoni Budaya, Instrumen Pendidikan, Konservasi, dan Kewirausahaan," in Seminar Internasional Riksa Bahasa XII: Peranan Bahasa Indonesia sebagai Literasi Peradaban, UPI Bandung, Indonesia, 2018, pp. 739-750. [Online]. Available: http://proceedings.upi.edu/index.php/riksabahasa

[8] S.A. Aziz, "Literasi Folklore: Transmisi Karakter Luhur Dalam Sastra Lisan Bugis Makassar," in Kongres Bahasa Indonesia XI, 2018, pp. 1-17. [Online]. Available: http://repositori.kemdikbud.go.id/id/eprint/11169

[9] H. Halimatussakdiah, R.K. Yuda, and F. Junaidi, "Literasi Sastra Folklor pada Anak Sekolah Dasar," in Proc. Konferensi Nasional Bahasa dan Sastra V, pp. 125-133, 2019.

[10] N. Nurgiantoro, Sastra Anak Pengantar Dunia Anak. Yogyakarta: Gajah Mada University Press, 2005.

[11] D. Barton and M. Hamilton, Local literacies: Reading and writing in one community. London: Routledge, 2012.

[12] D. Barton and M. Hamilton, "Local LiteraciesReading and Writing in One Community," Issues in Applied Linguistics, vol. 10, no. 1, pp. 87-92, 1999.
[Online].

https://escholarship.org/uc/item/8x8305h4

[13] M. Zed, Metode Penelitian Kepustakaan. Yayasan Obor Indonesia, 2008.

[14] J. Danandjaja, Folklore Indonesia. Jakarta: Pustaka Utama Grafiti, 1994.

[15] I.W. Harits, "Religious and Moral Values in Madura Folktales," Sirok Bastra, vol. 1, no. 2, pp. 243-249, 2018. DOI: $10.37671 / \mathrm{sb} . v 1 \mathrm{i} 2.27$

[16] D. Barton, M. Hamilton, and R. Ivani, Situated literacies: Theorizing reading and writing in context. Routledge, 2005.

[17] I.N. Azhar and B. Irawan, "Existence of Bhuju' as a Legend of the Madurese Society in the Levi-Strauss Perspective," in Proc. International Conference on Art, Design, Education, and Cultural Studies (ICADECS) 2019, Malang, Jawa Timur, Indonesia, 2019, pp. 131-139. [Online]. Available: http://icadecs.um.ac.id/?p=134

[18] M.H. Effendy, "Local Wisdom Dalam Tembang Macapat Madura," OKARA: Journal of Language and Literature, vol. 9, no. 1, pp. 55, 2015.

[19] S. Sulaiman, "Local Wisdom Values of Madurese Folklore for Character Building," in Advances in Social Science, Education and Humanities Research, vol. 174, pp. 113-117, 2018.

[20] M. Hefni, "Lok-Olok dalam Tradisi Lisan di Madura," KARSA Journal of Social and Islamic Culture, vol. 21, no. 2, pp. 198, 2015. DOI: 10.19105/karsa.v21i2.517

[21] I.N. Azhar, "Madurese Folktales Map Construction in Madura Island," in Kongres Bahasa Indonesia, 2018. [Online]. Available: http://repositori.kemdikbud.go.id/id/eprint/10106

[22] S. Utami and V.M.T.L. Tobing, "Nilai-Nilai Pendidikan dalam Komunikasi Kejhung Madura dan Relevansinya bagi Penanaman Karakter Berbasis Kearifan Lokal Madura," Journal of Communication, vol. 12, no. 2, pp. 133-140, 2018. Available: https://journal.trunojoyo.ac.id/komunikasi/article/vi ew/4515/3143 